\title{
The Impact of Child Labour on Children's Educational Achievement in Ganta Afeshum Woreda, Tigray State, Ethiopia
}

\author{
Worku Dibu \\ Department of Civic and Ethical studies, Wachemo University, Ethiopia \\ workud123@gmail.com
}

http://dx.doi.org/10.18415/ijmmu.v6i4.996

\begin{abstract}
Child labour is an important aspect of social and economic reality that surrounds us although it is sometimes unnoticed. It is the severe problem of the world in general and the sub-Saharan countries like Ethiopia in particular in which children are considered an asset and means to improve livelihood of their family at the expense of their education. The attempt towards the elimination of child labor in Ethiopia is still lagging compare to the rest world. This in turn is affecting adversely the accumulation of human capital. Thus, the researcher was intended to assess the impact of Child Labour on Children's Educational Achievement in Ganta Afeshum Woreda and give the possible solution to overcome this problem. To realize this objective, the researcher employed qualitative approach and used in depth interview, FGD, key informant interview, personal observation data collection instruments and employed descriptive research and purposive sampling technique. The researcher analyzed the finding qualitatively through interpretation, description and summarization of the data. As the finding of the study indicates child labour is sever in rural area than urban area and also girls are more exposed for child labour than boys, children are involved in domestic and non-domestic productive activities. The attitude of communities toward child labour is also positive; they consider children as valuable asset for contributing family income. The views of households on working children arise commonly from their poor knowledge about the issue and is directed by traditional outlooks of uprooting 'milk teeth', that is seen as a shift from childhood to adulthood. As the finding indicates, Child labour has an impact on children's educational achievement by making them: repeated the class, absenteeism from class, drop out, make very tired, shortage of times for study and reducing the chance to access education, beside this, as the finding indicate attitude of the communities, employers, poverty coupled with limited access to credit, health and family size as well as the abusive practices are the challenges that hamper eliminating of child labour. Finally, as the finding indicate the local administrator strategy of employing one sector, one children and work with NGOs, private sector and public sectors play significant role via improving the future childhood of children.
\end{abstract}

Keywords: Child Labour; Educational Achievement; Children 


\section{Introduction}

The definition of child labour is not as simple and straightforward as it may appear rather it is very controversial issue. But the United Nations, as highlighted by Nkurlu, defines child labour as "all forms of economic exploitation of a child or, any work that is likely to be hazardous or interfere with child's physical, mental, spiritual, moral or social development"(Nkurlu, 2000:1).

Child labor remains a serious problem in the world today. According to the estimation of International Labor Organization (2010), about 215 million child laborers between the ages of 7 and 14 are found in the world, the Sub-Saharan Africa has the highest incidence of children in economic activities. That is $28.4 \%$ of labor in Sub-Saharan African countries come from child labor whose age are between 5 to14 years old, and the attempt towards the elimination of child labor is still lagging behind compare to the rest world. These in turn is affecting adversely the accumulation of human capital(Ibid).

Like others Sub-Saharan Africa countries, Ethiopia has also highest rates of child labor in the world. About half of children whose age are between 5 to 14 years old are engaged in the economic activities in Ethiopia and that exhibited the low rate of school attendance and grade completion (CSA, 2001).

Though the Ethiopia government has been ratified international convention of children and incorporate in her domestic law, children are still resort to domestic work i.e. washing, cooking, fetching water, taking care of young siblings and animals; Productive activities i.e. cultivating, planting, weeding, harvesting, post-harvest activities and marketing etc. Children are also being hired out as laborers to others as agricultural laborers to pay the debts of their parents.

The main rational that forced the researcher to conduct this research is that Child labour is the most deep-rooted problem for third world countries that affects the future life of children and the human resource of a country. Though the rate and degree of child labour exploitation is varied from country to country depending on the economic development they under scored, in most third world countries many people considered children as an asset and means to improve their livelihoods. As a results of such thinking of the society in general and the family in particular, child labor and abuse is a serious problem particularly in developing countries. Ethiopia is also one of the developing country in which child labour is practiced.

Child labour is a critical human rights problem because it denies the child's time to take part in activities that are useful for the 'normal' growth of the child like time to go to school and time to play.

Though the aforementioned problems are also clearly revealed in Tigray Region in general and Ganta Afeshum Woreda in particular; there is no research finding that clearly sheds light on the impacts of child labour on children's educational achievement in study area. Although few studies conducted on child exploitation in Ethiopia, they provide only blurred information that is not sufficient to understand fully the extent of the problem and predominantly its impact on educational achievement. Therefore, the researcher intended to conduct their research to fill the above research gap.

\section{Study Area}

The study area is located in Ganta-Afeshum District which is located in Eastern zone of Tigray State. It is one of the Nine Districts found in the East Zone of Tigray state. It is located at $898 \mathrm{Km}$ and $120 \mathrm{~km}$ away from Addis Ababa and Mekelle cities respectively. It is bordered by Gulomekeda District in the North; Saesie-Tseadaemba in the East; Hawzein in the South; Werii-Lekhe in South West; and AdiAhferom in the West. 


\section{Methodology}

The purpose of this study was to assess the impacts of Child Labour on Children's Educational Achievement in Ganta Afeshum Woreda and to identify the cause on their educational achievement. To realize the stated objectives, the researcher employed descriptive research design and qualitative method of research to analyze and collect data through personal observation, focus group discussion, in-depth interviews, case studies and key informant interviews. The main rationale that has drawn the attention of the researcher to choose or conduct qualitative approach was: qualitative research is important "to understand, in-depth, the viewpoints of research participants, and it is also the voice of marginalized" (R. Maldonado, nd). Due to this fact, the researcher opt qualitative research; because the researcher needs to illuminate the very sensitive and detail information about the perception, feelings and experiences of children, parents, school communities and local administrators towards child labour.

\subsection{Methods and Instruments of Data Collection}

Both primary and secondary data were employed in the study. The primary data was collected through face-to-face discussion and personal observation, by focusing on respondents strategically and purposefully select to conduct in-depth interview and key informant interview, case studies and FGD. The secondary data has been primarily consisted of the books, journals, Government Official Reports, internet and other relevant national and international human rights instruments.

\subsection{Data Collection Instruments}

As indicated above the researcher employed qualitative methods of data collection. Thus, the Instruments that were important to collect the relevant data by the researcher were the following: indepth interview, case studies, focus group discussion, key informant interview and personal observation.

\subsection{Method of Sampling and Procedures of Data Collection}

This study employed purposive sampling methods and select one Woreda among Nine woreda found in Eastern Tigray Zone based on its proximity. Likewise, the researcher choose seven primary schools from 33 primary schools find in the Woreda by taking into account their direct or indirect involvement in the problem and/or knowledge of the subject matter or magnitude of the problems, and the existence of hidden child labor exploitation and transport accessibility. Since it is also difficult to take sample from grade 1-8, each primary school grade eight students were selected for the study. The researcher do this, because they can give adequate information; they also take the standardized exam thus it makes easy to known child labour impact on educational performance. The main rationale for choosing purposive sampling by the researcher is due to:

Purposeful sampling is usually suitable in qualitative research method because it allows the researcher to select participants based on their unique experiences in the studying issue so as to enhance the richness of information that is mandatory for detail and accuracy of the research being investigated. 


\subsection{Secondary data collection}

Secondary data will be collected from the ten sample kebele's primary school director office and Woreda's Education Bureau on the issues related with repetition' absenteeism, drop-out rates and result of the students to assess the impacts of child labour on children's educational achievement. Annual reports from each primary school director office and Worde's Education Bureau will be reviewed by the researcher.

\subsection{Method of Analysis and data Processing}

The study entitled as assessing the impacts of child labour on children's educational achievement in Ganta Afeshum Woreda employ qualitative method of data analysis for the data collect through personal observation, focus group discussion, in-depth interview, and key informant interviews from the respondents. The data obtain through the aforementioned method of data collection organize in line with the objectives of the research. For this purpose, Qualitative data records by taking detail notes and cassette recordings. At the end of each field work, researcher and coordinator will discuss the findings, describe respondents in terms of key variables, order the data, reduce them and classify or code (sort out), display and summarize , and finally interpret and draw conclusions about the data.

\section{Result of the Study}

This chapter presents some of the findings from the research carried out on the impact of child labour on children educational achievement in Ganta Afeshum Werda, Tigray State, Ethiopia.

\subsection{Impact of child labour on children educational achievement}

The safe growth of children is the only way for any society to thrive and ensure future survival. The safe future survival of children is ensured when children build by education. Children who engage in domestic and non-domestic working areas' safe growth is largely remains at risk which has negative bearings on national development as children are the next generations to chain the past with the future through their productive role in society. Children who enter into the labor market in both the formal and informal economic sectors in the country suffer tremendously. This in turn brings poor children educational achievement or absence of accessing school.

As the report indicate by each primary school, majority of the students that scored low result are those children who are absent from school or have family health or economic related problems. Child labour reduce the time that helps to study the lesson by make them to feeling boring, tired and hoplessness.It also impose high psychological impact especially for those children who work for others to pay their debt of the family. In short, the impact of child labour on children educational achievement is seen from the following angle based on the response of respondents: 


\subsubsection{Reducing the chance to access school}

As the respondents clearly point out child labor had sever influence on children' educational prospects. The parents were not willing to send their child to school since they considered children as a means and asset to improve the livelihood of the family. Child labour is seen as the common valuable practices for fulfill the demand of the family and assisting the family by performing different domestic and non-domestic working activities including sending children for repayment of family debt. The testimony of one respondent put as follow:

I am not educated until 22 years, I have got an opportunity to learn after the kebele manger forced our family me to send to school. Prior to this year the, our parents determined not go to school

Since he has seven small brother and sister, he obliged to feed the belly of the family instead of join School. He regretted and irritated by the decision his parents made at that time. Because now some of his friend that found in equal age are joined universities.

From this, one can conclude that beyond awareness creation of the children family, the local administrator should arrange access to credit for the households that found on the low or destitute living standard. Unless and otherwise only insisting the households to send the child without putting a solution cannot alleviate the problems because if the household to do that the children themselves forced to terminate the class due to lack of at least the basic needs.

\subsubsection{Absenteeism}

As the respondents of the research reported although some children get the opportunity to learn, their overburden tasks provided before they go to school and after they come to the class obliged to miss their class frequently. The participant of the research stated that when the student repeatedly absent from class, they cannot cover the content and failed to understand the subject matter at it is required which undoubtedly later affect their academic performance.

As one of the interview from one primary school said I am 13 years old. I absent from the class repeatedly since I have irrigation land, my father ordered to cultivate the onion and sell in the market. Unless and otherwise my father doesn't give a fraction of cents for buying pens and exercise book as well as buy school uniform. Thus, I determined to absent from the class regularly to cultivate the onion. During my absenteeism, the teachers give a lot of assignment. But I cannot cover it; even I don't know how to work since I cannot learn it.

As the respondent of research participants from different elementary also school reported, they don't actively participate in the class because of cumbersome domestic and non-domestic works that bring sever boring to do task. Beyond this, since they missed class because of absenteeism they don't know what they have learnt in the previous class.

As one of the interviewee of research participant said I am the one I have in trouble of poor class participation. I always bother how can I accomplished the activities like baking Enjera, fetching water 2-3 times, washing clothes and brewing Tella etc. Since I divert much of attention about the domestic and non-domestic activities, I don't bother about the learning teaching process. Class activities and performing well is the noon hallucination for me because knowledge is not acquired without study but I have not time to do it. Even at the night time, I cannot study well since our family said please don't finished the light. 
Moreover, another interviewee also said that child labour pose sever impact on my education. Since I exhaust much of our time on very boring and cumbersome activities, I can't study properly do class work in the proper manner.

I have lost my parents because of HIVAIDS. Since I am the biggest one from the members of the family, the responsibility of leading and feeding our smallest sisters and brothers is imposed on my hand. Though one of my teacher gives support like pens and exercise books, this is not adequate support even for me. Because of this fact, I determined to employed others homes and improving and feeding the stomach of my smallest brothers and sisters.

The testimony of the above interviewees clearly showed that both boys and girls regularly absent from the class to do the domestic and non-domestic activities. This is directly responsible for low academic performance of the children. Hence, the concerned stakeholders primarily the local government should exhaust their unreserved effort to create awareness towards the household don't order children to resort into cumbersome domestic and non-domestic activities. If the households don't refrain from such kinds of activities, the local administrator should refer to the court so as to get legal punishment. Because Ethiopia ratified international convention of children and incorporates into domestic law and access to primary education is a global agenda. Ethiopia is also one of the country that work to realize Millennium Development Goal.

\subsubsection{Shortage of Time to Involve in Educational Activities}

One of the research participant reported that, she become busy when back from school, during night and weekends. She also said that due to her being busy in home she couldn't properly carry out her homework. She pointed: "since I am busy of all the days after and before school, mostly I work my assignment using break time, which is very short time to complete the whole task" other respondents also consolidate the idea of her by saying she is the only female child in the family, several domestic activities given to her results delaying most of the time to perform her homework since she did not have enough time to do. Key informants also suggested that children work beyond their capacity, after school they engaged in domestic activity sometime up to six and seven hours of the night and wake up early at about 2 a.m. Even they do not let them to play out.

\subsubsection{School Drop Out}

As mentioned by some interviewees, all the aforementioned problems are ended with dropping out of school.

As teachers reported student drop out from the school since they believed that they have responsibility to improve the living standard of the family and respecting the words of the family. Especial some female student drop out from grade eight by leaving the country and traveling to Saudi Arabia to improve the life of the family. And others students interrupt learning since they forced to marry at their early age. The parents forced the child by saying please let you show your future life, we are closer to death, thus, we don't want to death before we say your fortune. If they refused the word of their parents, they cannot learnt because their parents don't buy pen, uniform, exercise book and other necessary basic need for them. Moreover, the children considered refusing or opposing the word of the family is just like the symbol of curse (FGD, May 2016).

According to the response of teachers from different elementary and junior school, the tendency of traditional thinking developed by the children and positive attitudes of the household regarding child 
labour pose great impact on children educational achievement. The children considered ignoring every words of the family is the sign of curse and the manifestation of disrespect that bring future bad fortunate and the household also consider early marriage and send Saudi a sign of proud and prosperity. Hence, different stake holders like teachers, local administrators, NGOs and mass media play a significant role in awareness creation.

The response of our key informant also confirmed the above research participant ideas.

The key informant said that some girl students drop out from the class because of their family destitute economic situation triggered to fly in Saudi Arabia. Two students from our school go to Saudi Arabia to improve their family life via remittance and to make their illnesses mother to get medical treatment. And they think at least we can cure the sick mother assist the remaining sisters and brothers properly by covering the necessary material and payment for transport and renting house (key informant with principal school Director, April 2016).

She was asked about her educational background and responded as she was failed to pass grade four once and six grade two times. Questions were raised whether to continue her education or not. She answered, "Thought I have interest to do that, currently I don't want to continue my education due to the economic problem of the family." Similarly, other research participants, who is 14 years old female children, responded that

I dropped out of the school when I was in 8 grade. The crucial reason of termination was as a result of the family's economic problem. I was wanted to contribute for the family. My father is farmer whereas my mother is brewing Areki. My elder sister is also dropped out of the school and helping the family by selling Areki(Interview, March2016)

From the aforementioned respond we can estimated that children forced to flee from the country's to abroad by interrupting their class is simply become bread winners and get better medical access. The family also triggered the children to interrupt their education and engage other income generating activities especially by going to Arabia countries since they assumed dramatic change is bring via this track. They stressed on that the reason was they want to improve their living standard if it is possible very luxuries life vie remittance. But, in reality since the go to Saudi illegally by brokers via the red see most of they are exposed for miserable life death by sinking the red sea or if they are fortunate escape from death they resort on sex industries which is also a sever child labour.

Table .1. Number of Interrupted students with its reasons in 2005 E.C

\begin{tabular}{|c|c|c|}
\hline Reasons & Boys & Girls \\
\hline Illness & 10 & 4 \\
\hline Migration & 10 & 4 \\
\hline Distance & 6 & 1 \\
\hline Marriage & 1 & 3 \\
\hline Hopelessness & 8 & 3 \\
\hline
\end{tabular}

Source: Ganta Afeshum Educational Bureau Report, 2005 E.C

From the above table, we can conclude that migration is one of the major responsible factors for children interruption. Thus, the local as well as the regional and federal government should do collectively to fight illegal broker that send abroad and bring in front of courts. In addition to this, as far as the government potential is allowed, they should give some assistant for the orphaned and children's 
come from economical poor family. Moreover, government should also encourage indigenous and nonindigenous civil society to work on the areas of fighting against child labour.

\section{Conclusion}

In this study, it was found that both boys and girls aged between 9 and 16 years old drop out of school and engage in domestic work in order to earn a living. Evidence therefore indicated that domestic work has adverse effects on both boys' and girls' schooling. In this regard, domestic work negatively affects child domestic workers' schooling as their attendance becomes poor and eventually children drop out of school to concentrate on work. For children who combine work and school, their performance at school becomes very poor as they cannot concentrate on their studies and work at the same time. Poor performance coupled with school drop outs entail that children's educational advancement is affected. More so, children's enrollment is also affected as they opt for domestic work at the expense of education.

\section{References}

Burgess, Robin and Rohini Pande. (2003). Do Rural Banks Matter? Evidence from the Indian Social Banking Experiment. Retrieved on February 18, 2008,from http://www.princeton.edu/ rpds/downloads/seminar_papers/burgess_rural_banks.

CSA 2001. Ethiopia: Child Labour Survey Report, Federal Democratic Republic of Ethiopia, Central Statistical Authority.

Cunningham, Hugh and Pier Paolo Viazzo (ed) (1996) Child Labour in Historical Perspective 1800-1985Case Studies from Europe,Japan and Colombia.Florence,UNICEF,International Child Development Center.

Employment Division Economic and Social Development Department ,2013.Children's work in the livestock sector: Herding and beyond Gender, Equity and Rural.

Federal Democratic Republic of Ethiopia, 1995.The Ethiopian Federal Democratic Republic Constitution. Addis Ababa: Berhanena Selam Printing Enterprise.

ILO,2010.Facts on Child Labour.

Nkurlu, J.I., 2000. Child Labour: Background Paper, Africa News Letter 2/2000:

R. Maldonado (nd). Sample Qualitative Research Proposal: A Phenomenological Pilot Study of Energy Healers Expertise and Recommendations for Energetic Disaster and Trauma Relief Training.

Sarah A. and Morgan, B.A, 2008.Credit And Child Labor: The Impact of Parents 'Access to Credit on Children's Labor. A Thesis submitted to the Graduate School of Arts \& Sciences at Georgetown University in partial fulfillment of the requirements for the degree of Master of Public Policy. 
The UN Convention on the Rights of the Child @ United Nations, June 2010.

UNICEF (2005). Child Labour Today—End Child Exploitation—. U.K. (not specified): Author.

Weiner, Myron (1991). The Child and the State in India. Princeton: Princeton University Press.

Weston, H. Burns (ed.), 2005. Child Labour and Human Rights: Making Children Matter. London: Lynne Rienner Publisher, Inc.

\section{Copyrights}

Copyright for this article is retained by the author(s), with first publication rights granted to the journal. This is an open-access article distributed under the terms and conditions of the Creative Commons Attribution license (http://creativecommons.org/licenses/by/4.0/). 